17. Зайони В.Н., Горошков Ю.В., Лотоикий Г.И. и др. Проведение специального инженерно-геологического обследования Н. Поволжья. Отчет по НИР. Саратов, 1981. Т. 1.381 с.; Т. 2.412 c.

18. Лоточкий Г.И. Об интенсивности развития овражной эрозии Саратовского Поволжья // Закономерности проявления эрозионных и русловых процессов в различных природных условиях. М., 1987. С. 77-78.

19. Лотоикий Г.И. Некоторые особенности развития склоновых процессов Саратовского Правобережья // Вопросы физической географии и геоморфологии Нижнего Поволжья. Саратов, 1975. Вып. 3 (7). С. 63-72.

20. Востряков А.В. Геология Саратовского района и геологические процессы в окрестностях города. Саратов, 1977. $113 \mathrm{c}$.

21. Зайони В.Н., Горошков Ю.В., Макаров С.А. и др. Составление карты современных физико-геологических процессов масштаба $1: 200000$. № ГР 21-77-308/10; Инв. № 280. Саратов, 1982. T. 1.350 c.

22. Худяков Г.И., Никифоров А.Н. К вопросу о геологогеоморфологическом строении территории города $\mathrm{Ca}$ - ратова // Недра Поволжья и Прикаспия. 2001. Вып. 27. C. 20-24.

23. Иванов А.В., Макаров В.З., Чумаченко А.Н. и др. Саратовский научно-образовательный геоэкологический полигон / Под ред. А.В. Иванова, В.З. Макарова, А.Н. Чумаченко. Саратов, 2007. 286 с.

24. Худяков Г.И. К проблеме озеленения г. Саратова (о возможной программе действий) // Тр. НИИГеологии СГУ. Нов. сер., Т. Х. 2002. С. 122-125.

25. Башкатов А.Н. Овражно-балочная сеть как элемент ландшафтно-экологического каркаса г. Саратова (методологические принципы и историческая реконструкция) // Географические исследования в Саратовском университете / Под ред. Е.А. Полянской. Саратов, 2002. C. $97-107$.

26. Иванов А.В., Короновский А.А., Минюхин И.М., Яиков И.А. Определение фрактальной размерности овражнобалочной сети города Саратова // Изв. вузов. Прикладная нелинейная динамика. 2006. Т. 14, № 2. С. 64-74.

27. Иванов А.В., Яшков И.А. Экологические опасности Саратовского Поволжья: Интерактивный атлас. М., 2007.

\title{
ОСОБЕННОСТИ ПЕРМСКИХ И ТРИАСОВЫХ ОТЛОЖЕНИЙ НАДСОЛЕВОГО КОМПЛЕКСА ГРЕМЯЧИНСКОГО МЕСТОРОЖДЕНИЯ КАЛИЙНЫХ СОЛЕЙ
}

\section{Т.Ф. Букина' ${ }^{1}$ З.А. Яночкина' ${ }^{1}$, Г.А. Московский}

\author{
Саратовский государственный университет, \\ кафедра минералогии и петрографии \\ ${ }^{1}$ Отделение геологии НИИ ЕН СГУ \\ E-mail: bukina tf@land.ru \\ E-mail: MoskovskyGA@infosgu.ru
}

Исследование надсолевых отложений Гремячинского месторождения сильвинитов позволило установить сокращенный, по сравнению с другими площадями Прикаспийской впадины, разрез как пермских, так и триасовых отложений. Выявлены фрагментарные части разреза средней и верхней перми, нижнего и среднего триа$\mathrm{ca}$, отсутствие отложений верхнего триаса и следы верхней юры. По данным вещественного состава прослежены геологическая история региона, генетические особенности и закономерная смена фаций от континентальных в верхней перми к лагунным в нижнем триасе, бассейновым терригенным образованиям в анизийском ярусе, затем к морским солоноватоводным водорослевым в ладинском веке среднего триаса. В статье приведены данные описания шлифов и иммерсионных препаратов. Толща, залегающая на галогенных отложениях, отделена от вышележащих верхнемеловых отложений перерывом в объеме верхнего триаса, всей юры и нижнего мела.

Ключевые слова: месторождение, сильвиниты, надсолевые, пермские, триасовые отложения.

Features of the Permian and Triassic beds in the supersalt complex from the Gremyachinskoye potassium salt field

\section{T.F. Bukina, Z.A. Yanochkina, G.A. Moskovskij}

Study of the supersalt beds from the Gremyachinskoye sylvinite filed has shown the sections of both, the Permian and the Triassic

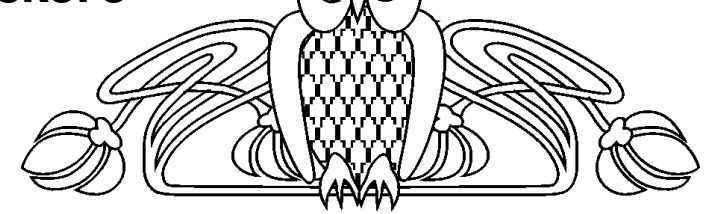

beds to be curtailed relative to other areas of the Pricaspian Depression. Fragmentary parts of the Middle and of the Upper Permian beds have been revealed alongside with the Lower and the Middle Triassic, missing upper Triassic beds and the traces of the Upper Jurassic deposits. The geologic history of the region, the genetic features and the regular facies succession have been traced from the material composition data: from the continental ones in the Upper Permian to lagoonal in the Lower Triassic, to basin terrigenous bodies in the Anisian and to marine brackishwater algal ones in the Middle Triassic Ladinian age. The data on the rock thin sections and immersion specimen descriptions are presented in the paper. The sequence, superposing the halogenic deposits, is separated from the overlying Upper Cretaceous beds with a gap involving the Upper Triassic, the whole of the Jurassic and the Lower Cretaceous.

Key words: filed, sylvinite, supersalt, permian, triassic beds.

Статья написана по материалам, полученным при изучении пермо-триасовых отложений, перекрывающих галогенные отложения месторождения и вскрытых скв. 13. Между калийными солями и рассматриваемым ниже комплексом встречаются слои хемогенных ангидритов с тонкими прослоями галита (рисунок). Надсолевой разрез на месторождении начинается с глубины 884 м, где на ангидритах залегают следующие 
отложения. В интервале 884,5-816,2 м выделяется пачка красновато-бурых, красноватокоричневых, коричневых с красноватым оттенком, буровато-красных аргиллитоподобных пород, сложенных глинистым, карбонатным и алевритовым материалом, пигментированных гидроокислами железа. Пачка имеет типично пермский облик. Пятнистое расположение компонентов в этих породах, скорее всего, связано с деятельностью грунтоедов.
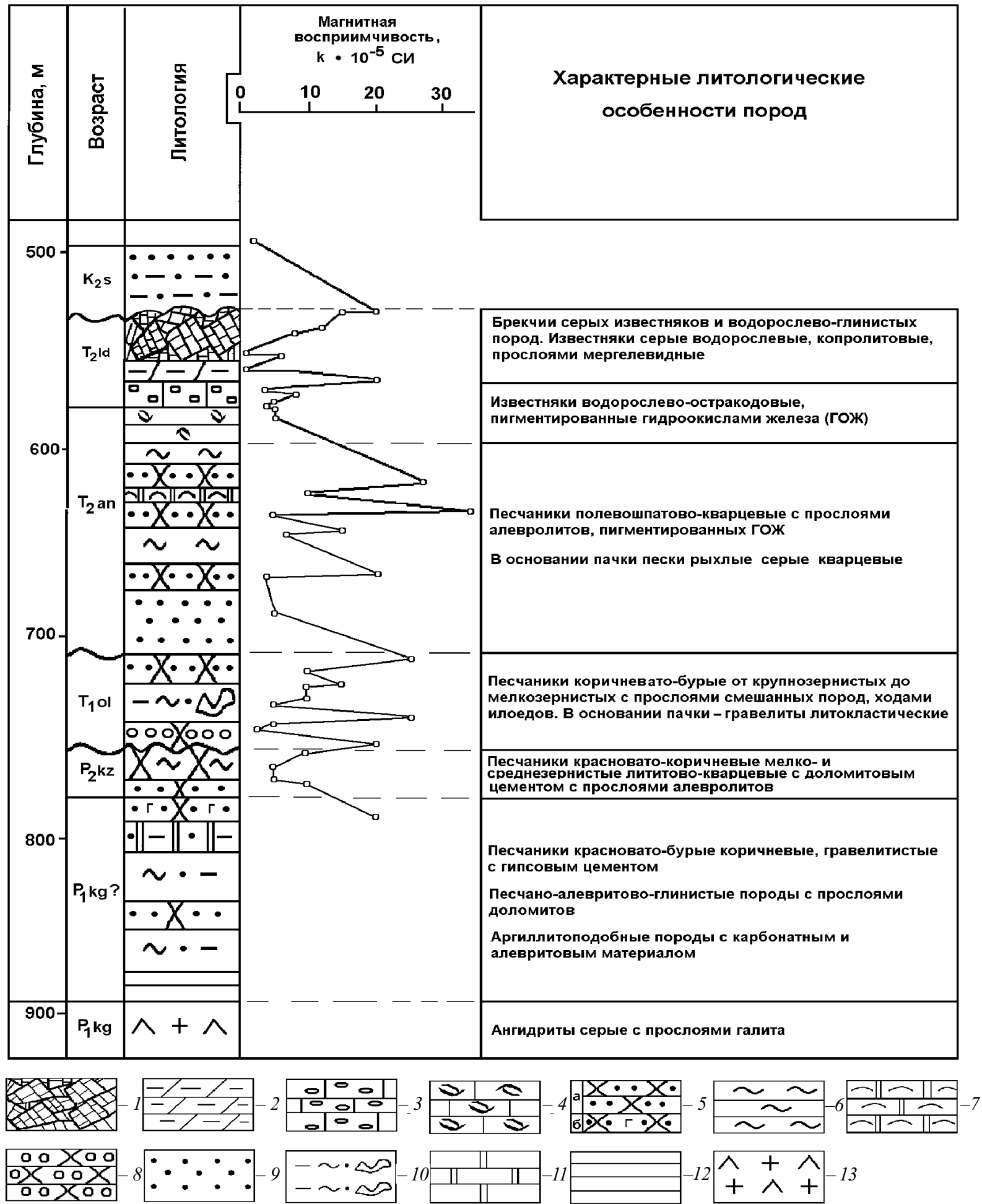

Разрез пермских и триасовых отложений надсолевого комплекса Гремячинского месторождения калийных солей, скв. 13. Магнитная восприимчивость пород приведена по данным В.Н. Фролова: 1 - брекчия известняков; 2-4 - известняки: 2 - мергелевидные; 3 - копролитовые; 4 - остракодовые; $5 a$ - песчаники; 56 - песчаники с гипсовым цементом; 6 - алевролиты; 7 - доломиты с остатками строматолитов; 8 - гравелиты; 9 - пески; 10 - смешанные песчано-алевритоглинистые породы с ходами илоедов; 11 - доломиты; 12 - аргиллиты; 13 - ангидриты с прослоями галита 
В основании пачки наблюдается смешанная глинисто-железисто-карбонатная алевритистая буровато-красная плотная крепкая порода с пятнами оглеения округлой формы, размером $1-1,5$ мм. C $\mathrm{HCl}$ она не реагирует. В ее минеральном составе присутствуют глинистое вещество, гидроокислы железа, доломит, кварц, полевые шпаты, гидрослюда, мусковит, хлорит, серицит. По составу она отличается равномерным распределением компонентов, связанным с хорошей сортировкой материала. Преобладающий размер частиц 0,01-0,005 мм. Тонкодисперсный карбонат (доломит) имеет биогенную природу, связан с остатками сине-зеленых водорослей, а также с переотложенными скелетными элементами кокколитофорид. Часть скоплений водорослей доломитизирована. Относительно низкое содержание кварца и слюд, рассеянных среди карбонатов алевритовой размерности, свидетельствует о незначительном поступлении в зону седиментации терригенного материала из удаленных областей сноса. Полная доломитизация карбонатов обусловлена формированием осадков в осолонённом водоёме. Выше в интервале 844,8-840 м встречен прослой мелкозернистого кварцевого песчаника с глинисто-ангидритовым цементом, образованным в условиях восстановительной среды в прибрежной части осолоненного бассейна в зоне водотока с низким энергетическим уровнем. Но уже на глубине 824,2-822,5 м карбонаты растворены, но участками выявляются в виде реликтов в массе глинистого вещества, что определяет отложение осадков в условиях опреснения вод.

В пачке красноцветных, буро-красноцветных, коричневых песчаных, алевритовых и глинистых отложений самых верхов кургурской части разреза (см. рисунок) на глубине - 798,3 м. залегает доломит мелкозернистый, песчанисто-алевритистый с линзами глинисто-железистого состава. Породообразующий карбонат составляет $80 \%$. Размер кристаллов варьирует от 0,03 до 0,05 мм. Они разделены бурым глинисто-железистым тонкодисперсным веществом, составляющим 15-17\%, но локально образующим более концентрированные линзы (50\% и более).

Неравномерно рассеяны в породе в разной степени окатанные алевритовые и песчаные частицы, в основном представленные кварцем с волнистым угасанием, обломками кремнистых пород, листочками слюды и хлорита. Редко встречаются таблитчатые зёрна плагиоклаза со слаборазличимыми полисинтетическими двойниками. Количество песчаных и алевритовых частиц повышено в участках скопления глинисто-железистого вещества. Структура породы мелкозернистая, кристаллически-зернистая, пятнами псаммитовоалевритово-пелитовая.

Основываясь на структурных и вещественных особенностях породы можно судить, что осадки формировались как хемогенные и хемогеннотерригенные в условиях лагуны, которая посте- пенно приобретала черты авандельты, заполняясь терригенным материалом.

Так, на глубине 795,2 м вскрыт песчаник коричневый с красноватым оттенком, неравномерно-зернистый до крупнозернистого, гравелитистый, локально алевритистый. Он отличается плохой сортировкой материала, помимо обломков осадочных и метаморфических пород, содержит обломки эффузивов и туфов. Порода сложена хорошо окатанными соприкасающимися обломками размером от 2-3 мм и мельче, погруженными в кристаллически-зернистый цемент гипсового, локально полугидратного состава.

В составе обломков преобладает кварц, часто с мозаичным угасанием. Обломки метаморфических кварцитов и глинисто-кремнистых пород характеризуются различными структурами. В кварцитах наблюдается кварц двух генераций - вмещающий и жильный, в виде прожилков, секущих крупные кристаллы. В обломках кремнистых пород с неравномерной и тонкозернистой структурой изредка угадываются реликтовые кристалло-литокластические и витрокластические элементы туфов. Однако большая часть глинистокремнистых пород с ориентированной слоистой текстурой и криптозернистой структурой, повидимому, являются осадочными образованиями. В небольшом количестве встречаются обломки глин, аргиллитов и кварцевых алевролитов. Переотложенные мелкозернистые и тонкозернистые доломиты частично выщелочены с образованием пор. Встречаются обломки с реликтами крупных ромбоэдров доломита замещенных халцедоном. В этом случае от доломитовых кристаллов сохраняются наружные зоны типа «рубашек», окаймляющих новообразованный минерал. Полевые шпаты представлены относительно свежим плагиоклазом с тонкими полисинтетическими двойниками. Сpeди алевритовых частиц преобладает кварц.

Структура породы крупнопсаммитовая до псефитовой.

Это единственный из интервалов (см. рисунок), в котором песчаный материал сцементирован гипсом. Его крупные (до нескольких сантиметров) кристаллы в цементе базального типа, отражающие свет, хорошо определяются при макроскопическом описании пород и могут служить надежным репером для проведения границы между кунгурским и казанским ярусами.

Выше по разрезу (790,8 м) встречены песчаники среднезернистые, лититово-кварцевые с доломитовым цементом. Породы коричневатосерые, относительно светлые с серыми пятнами оглеения, с плитчатой отдельностью. $\mathrm{C} \mathrm{HCl}$ они не реагируют. В их составе определяются кварц, полевые шпаты, обломки кварцитов, кремнистых, глинисто-кремнистых пород, эффузивов, туфов, доломитов содержатся глинистое вещество, хлорит, гидроокислы железа, ангидрит.

Песчаники сложены слабоотсортированными терригенными обломками размером от 0,05 
до 0,5 мм с преобладанием среднепсаммитовых (0,25-0,3 мм). Содержание кварца в них достигает 40-50\%. Часто встречаются таблитчатые, свежие зёрна плагиоклаза с тонкими полисинтетическими двойниками и реже - калиевые полевые шпаты, представленные микропертитом. В сумме до 30\% присутствуют обломки различных пород - кварциты мелкокристаллические с гранобластовой структурой, прозрачные с небольшим количеством включений. С трудом различаются обломки осадочных кремнисто-глинистых, кремнистых пород и туфов, возможно, поставлявшихся из единой толщи на источниках сноса, где количество туфогенного материала не было однородным. Обломки эффузивов, сложенные призматическими кристаллами плагиоклаза, редки. Стекловатый базис в них хлоритизирован, присутствует в небольшом количестве. По составу эти породы отвечают андезитам.

Мелкокристаллический доломит в цементе заполняет поры, образуя агрегаты ромбоэдрических кристаллов размером 0,03-0,05 мм, иногда крупнее или мельче, находящихся в сростках с глинистым веществом, пигментированным гидроокислами железа.

Можно предположить, что часть цементирующего доломита образовалась из обломков в результате их перекристаллизации на стадии раннего диагенеза. Среднезернистая структура терригенного материала свидетельствует об относительно хорошей сортировке частиц, о их транспортировке активными водотоками, об отложении в береговой зоне в пределах авандельты, впадающей в осолоненную лагуну, поскольку все карбонаты осадка доломитизированы. Относительная свежесть материала, свойственная пермским образованиям, сохраняется. Выветривание материала на источниках сноса было малоактивным, протекая в условиях аридного климата [1]. Локализация питающих провинций на протяжении рассматриваемого периода, повидимому, сохранялась.

На глубине 777,6 м (см. рисунок) песчаники сменяются красновато-коричневыми плотными мелкозернистыми железисто-глинистыми алевролитами, которые по внешнему облику напоминают аргиллиты. В их составе наблюдаются явно повышенное содержание пластинчатых минералов - мусковита и хлорита. Как правило, концентрации пластинчатых минералов связаны с конечными водоемами стока. Следовательно, в конце перми бассейн на данной территории становится бессточным.

Эти данные подтверждаются результатами иммерсионного анализа. В легкой фракции здесь установлены многочисленные железистоглинистые агрегаты, сцементированные фрагменты самой породы. В тяжёлой фракции преобладают рудные элементы $(13,4 \%)$, лейкоксен $(10,3 \%)$ и лимонит $(63,6 \%)$, отражая окислительный характер мелководной среды седиментации. Та- кими отложениями завершается крупный тектоноседиментационный цикл поздней перми.

С глубины 768,5 м начинается сокращенный разрез нижнего триаса. В основании рассматриваемой пачки залегает розовато-коричневатосерый песчанистый литокластический гравелит (см. рисунок) с доломитовым цементом. Среди обломков пород в нём преобладают различные по структуре кремнистые разности (кварциты, кремнистые сланцы, яшмоиды из метаморфических комплексов), обломки пород карбонатных комплексов - доломиты, переотложенные из хемогенных осадочных образований. Судя по характеру окатанности, обломочный материал поставлялся из удалённых областей сноса, возможно, из эродированных образований самого разного возраста, в том числе нижнепермского, верхнепермского, каменноугольного, девонского и, вероятно, ордовикского (яшм с реликтами радиолярий) из юго-западных областей сноса. Перенос материала осуществлялся водотоками с активной гидродинамикой. Доломитовый состав цемента указывает на захоронение осадка в авандельте в условиях осолоненной лагуны.

В интервале 768,5-730 м (см. рисунок) наблюдается переслаивание красновато-коричневых, красновато-бурых, реже серовато-коричневых крупно-, средне- и мелкозернистых известковокремниево-кварцевых, доломито-кремневокварцевых и лититово-кварцевых песчаников с прослоями смешанных песчано-алевритоглинисто-железистых пород с многочисленными ходами и остатками илоедов, заполненных известковым материалом, а также алевритистых аргиллитоподобных глин.

По-видимому, эта часть разреза принадлежит оленекскому ярусу нижнего триаса при отсутствии индского яруса и связана с отложением в условиях заиленных лагун, заполнявшихся алевритово- железисто- глинистым материалом из разрушавшихся на близлежащих источниках сноса красноцветов верхней перми. Время от времени блуждающие языки авандельты поставляли в заиленную лагуну терригенный песчаный и алевритовый материал, в составе которого преобладали переотложенные фрагменты пород и минералов верхнепермских комплексов.

Возможно, на ход осадконакопления имели влияние гидротермальные растворы, о чем можно судить по обилию в этой части разреза следов деятельности личинок и остатков ядер простейших иглокожих организмов - голотурий - типичных представителей пригидротермальных сообществ современных морей и океанов [2]. Их ископаемые «предки» в большом количестве обитали в оленекском морском бассейне и проявляли особенную активность в заиленных западинах дна. Они встречены нами не только в бассейнах Прикаспийской впадины, но также на территории Мангышлака, где явно выражены синседиментационные гидротермальные процесы [3], и на территории Запад- 
ной Сибири, где гидротермальная деятельность сопровождала вулканические процессы $[4,5]$.

Граница нижнего и среднего триаса нами проводится по восемнадцатиметровой пачке светло-серых рыхлых песков аллювиального генезиса (706-724 м) с пониженной магнитной восприимчивостью (см. рисунок). К анизийскому ярусу условно относится пачка смешанных пород, периодически пигментированных гидроокислами железа до глубины - 583 м. Встреченный в основании пачки мелко-, среднезернистый песок имеет существенно кварцевый состав и редкие сцементированные обособления. Иммерсионный анализ образцов из интервала 598,5-706 м показал, что в лёгкой фракции (0,25-0,01 мм) количество кварца варьирует от 7,8 до $85,2 \%$, в среднем составляет $49,8 \%$, калишпатов - от 3,1 до $12,6 \%$, плагиоклазов от 2,2 до 6,7\%. Содержание слюд и хлоритов в сумме составляет более $5 \%$. Полевые шпаты имеют следы выветривания.

В тяжёлой фракции доля слюд (0-30\%) и хлоритов $(0,5-8,4 \%)$ весьма значительна, количество биотита составляет $28,9 \%$. Все чешуйки биотита имеют признаки лимонитизации. В связи с этим доля лимонита увеличивается от 3 до 26,4\%. На двух уровнях повышены магнитная восприичивость и содержание магнитного сульфида - пирротина (до 63\%), являющегося новообразованным и, возможно, гидротермальным минералом.

Выше рыхлых песков $(687,4$ м) вскрыты песчаники средне-, мелкозернистые полевошпатовокварцевые красновато-охристые с грубой плитчатой отдельностью и неопределёнными отпечатками на плоскостях напластования, не реагирующие c $\mathrm{HCl}$. Породы на 85-90\% сложены тесно соприкасающимися частицами размером $0,1-0,3$ мм. Более чем на 50\% материал представлен кварцем, на 20-25\% - полевыми шпатами, небольшим количеством обломков пород, в том числе кремнистых и глинистых, а также-метаморфических сланцев, сложенных кварцем, хлоритами и слюдами - биотитом и мусковитом Поликомпонентный состав является индикатором поступления материала из различных удаленных областей сноса.

Преобладающий в песчаниках кварц наблюдается в виде слабоокатанных и угловатых частиц с нормальным и реже мозаичным угасанием, имеет очень тонкие регенерационные каемки и выступы, участвующие в цементации породы. Источником его служили как осадочные, так и метаморфические комплексы.

Полевые шпаты представлены таблитчатыми зёрнами микроклина с решетчатой структурой, микропертита и пелитизированного плагиоклаза без признаков полисинтетического двойникования. Крайне редко встречаются зерна с полисинтетическими двойниками. Наличие измененных полевых шпатов свойственно среднетриасовым образованиям [1]. Локально увеличивается количество обломков метаморфических сланцев и слюд, хлорита, биотита, замещённых гидро- окислами железа. В этих участках цементация терригенных частиц осуществляется за счёт продуктов разложения пластинчатых железосодержащих минералов. Все обломки обволакиваются тонкими пленками глинистого вещества, пигментированного гидроокислами железа. В угловатых промежутках между зернами наблюдаются кристаллы галита постседиментационного генезиса. В небольшом количестве присутствует новообразованный доломит. В массе тонкодисперсного известково-глинистого вещества, пигментированного гидроокислами железа, явно присутствует переотложенный материал подстилающих красноцветных образований.

Интервал 706-583 м относится, вероятно, к анизийскому ярусу (см. рисунок), отличаясь более грубым пелитово-алевритовым материалом, сменяющимся на глубине 598 м песчаным. Периодически в окраске пород появляются красноватобурые оттенки, связанные с привносом переотложенных красноцветов нижнего триаса и верхней перми. Так, на глубине 687,4-598,5 м вскрыты красно-бурые, пятнами коричнево-красноватые породы - песчаники мелко-среднезернистые, преимущественно полевошпатово-кварцевые с прослоями мелкозернистых песчаников, а также глинисто-железистых алевролитов с песчаным материалом. На глубине 637,8 м встречен весьма интересный прослой песчаника с линзами строматолитовых обособлений и глауберовой солью в цементе. Примесь терригенного материала в колониях, которые можно отнести к зачаточным формам строматолитовых построек, ничтожна. Сочетание в породе тонкой биоморфная и крупной кристаллически-зернистая структуры. (0,1-0,5 мм и более) позволяет предполагать, что эти биогенно-хемогенные образования могли сформироваться в условиях «себхи».в береговой зоне осолоненной отшнурованной лагуны $[6,7]$.

Известняки на глубине 598 м на 80\% сложены тонкокристаллическим кальцитом, развитым по пелитоморфному. Они содержат терригенный материал размером 0,05-0,1 мм, представленный кристаллами кальцита и доломита с признаками окатанности, сгустками тонкозернистого кальцита, чешуйками слюды. В породе установлена ангидритизация створок остракод. В водорослевоостракодовых известняках 590 м, 588,3 м, 583 м, встречаются прослои, многочисленные створки остракод, длиной 0,1-0,2 мм, выполненые кальцитом и арагонитом. Они имеют оленекский возраст, то-есть переотложены из разреза нижнего триаса. Принадлежность остракод и харофитов к богдинской свите нижнего триаса доказана Д.А. Кухтиновым. Однако, по нашему мнению, субпараллельная ориентировка и большое количество разрозненных экземпляров являются признаком сортировки створок в процессе их переотложения. В анизийском веке основным источником сноса для формирования осадков, скорее всего, служили уже выведенные на поверхность, 
но слабо литифицированные, легко размываемые отложения нижнего триаса и отчасти пермские комплексы более удаленных областей.

В интервале 583,0-560,5 м (см. рисунок) породы представлены известняками глинистыми мергелевидными серых и светло-серых оттенков, а также копролитовыми с прослоями остракодовых и органогенных с более разнообразной фауной. Текстуры их не нарушены. Известняки сложены глинисто-карбонатными агрегатами размером 0,05-0,1-0,15 мм, содержащими остатки более мелких сине-зелёных водорослей.

Так, на глубине 564,3 м известняк глинистый водорослево-копролитовый (мергелевидный) зеленовато-серый плотный, крепкий тонкозернистый с редкими кристаллическими выделениями и включениями зёрен кварца, медленно реагирующий с $\mathrm{HCl}$. Он сложен кальцитом, доломитом, глинистым веществом, содержит кварц, пирит, ангидрит, мусковит, серицит, фосфаты. Примерно $80 \%$ известняка составляет пелитоморфный биогенный кальцит, сконцентрированный в копролитах различного размера. Преобладают сгустки размером 0,1-0,15 мм округлой и овальной формы, которые, в свою очередь, слагают копролиты более крупных организмов размером от 0,3 до $1 \mathrm{Mм.} \mathrm{В}$ массе пелитоморфного кальцита, существенно перекристаллизованного и, вероятно, доломитизированного с трудом выявляются реликтовые кокколитовые наноструктуры с частицами 0,005-0,01 мм и, возможно, остатки сине-зеленых и других водорослей менее 0,002 мм.

Примесь глинистого вещества (около 15\%) распределена неравномерно, и в некоторых копролитах её содержание повышено. Основная его часть расположена между соприкасающимися и неплотно прилегающими копролитами в смеси с пелитоморфным кальцитом и алевритовыми частицами, представленными кварцем, серицитом, мусковитом, доломитом. Общее содержание частиц терригенного материала размером 0,010,05 мм составляет не более $5 \%$. Существенное значение в породе имеет фрамбоидальный пирит, образующий рассеянные скопления. Размер отдельных фрамбоидов не превышает 0,01 мм. Они располагаются независимо от общей структуры вещества, занимая поля неправильной формы, величиной в несколько миллиметров, отражая распределение органики в исходном осадке.. Отмечаются органические остатки неясной принадлежности. Генезис пород биогенный, терригенно-биогенный. Имеются трещинки, заполненные доломитом, кристаллами ангидрита и солей постседиментационного генезиса.

Иммерсионный анализ образцов показал: что в лёгкой фракции преобладают глинистокарбонатные агрегаты (89,7-98,2\%), присутствует кварц $(4,5$ - 90,2\%), полевые шпаты $(0,2-1,7 \%)$. Акцессорные минералы тяжёлой фракции представлены чёрными рудными элементами $(0,2-$ $16,8 \%)$, цирконом $(0,7-6,1 \%)$, барит-целестином
(1,9-18,9\%), гранатом (0,2-2,8\%), фосфатизированными костными органическими остатками (9,9-34,4\%), агрегатными зёрнами неясного состава с включениями пирита $(26,2-76,4 \%)$.

В органогенных неравномерно раскристаллизованных известняках хорошо определяется исходная биоморфная структура материала с остатками остракод, двустворчатых моллюсков, а также фауны неясной систематической принадлежности.

Рассматриваемая часть разреза известковых водорослевых осадков с глубины 560-580 м относится нами к ладинскому ярусу среднего триаса, отличается от анизийских пониженным содержанием примеси алевритовых частиц и гидроокислов железа. Тип осадков близок сероцветному среднему триасу, описанному в южной части Прикаспийской впадины В.В. Липатовой [8]. Ограничение притока терригенного материала было связано с пенепленизацией в данный период окружающей суши, в том числе и горных сооружений. Об этом можно судить по материалам, представленным в монографии А.Д. Наумова [9].

В интервале 539,3 - 560,2 м (см. рисунок) разрез триаса представ лен брекчиями известняков, известково-глинистых пород и может быть отнесен к тектонически деформированным среднетриасовым образованиям. Превалируют в разрезе серые и тёмно-серые оттенки пород. Магнитная восприимчивость их снижается до $10^{-6}$ единиц СИ. Только в верхней части пачки, на границе с перекрывающими меловыми комплексами, характерно присутствие гидроокислов железа, пигментирующих глинистое вещество, располагающееся между крупными угловатыми фрагментами вышеперечисленных пород.

На глубине 549,5 м вскрыта известковоглинистая деформированная (мергелевидная) порода с ангидритом. Серая плотная и крепкая, с плитчатой отдельностью слоистость в ней по отношению к оси керна наклонена под углом $10^{\circ}$. Бурно реагирует с $\mathrm{HCl}$. Минеральный состав характеризуется присутствием мусковита и серицита, что свидетельствует о затрудненной циркуляции вод в бассейне седиментации. В породе наблюдается неоднородное распределение материала - пелитоморфного биогенного кальцита, рассеянного или сконцентрированного в копролитах различной формы и размеров, явно переработанного различными организмами. В некоторых копролитах обильно тонкочешуйчатое разноориентированное глинистое вещество с преобладанием гидрослюды и серицита, с примесью кварца и алевритовых частиц другого состава. Порода разбита трещинами. Одни из них - более тонкие и прерывистые заполнены глинистым веществом, в других, более «широких» раскристаллизован крупнозернистый кальцит и соли постседиментационного генезиса. Перемещение глинистого вещества было очень интенсивным и происходило в различных направлениях. Структура материала изменяется 
от пелитоморфной и алевритово-пелитовой до кристалличеки-зернистой. С точки зрения генезиса это, скорее всего, переотложенный материал карбонатных пород в результате карстовых явлений или периодического влияния грязевого вулканизма.

Брекчии известняков и известково-глнистых мергелевидных пород с обломками кристаллов кальцита на глубине 549 м - это серые плотные, довольно крепкие породы, во влажном состоянии тёмно-серые с округлыми 1,5-2 мм отпечатками флоры или фауны. Они бурно реагируют с $\mathrm{HCl}$. В их минеральном составе определяются кальцит, доломит, глинистое вещество, соли, кварц, полевые шпаты, пирит, ангидрит.

В результате иммерсионных исследований в лёгкой фракции определяется большое количество глинисто-карбонатных агрегатов - 76,6-89,9\%, 4,7-12,8\% составляет кварц, $1,1-3 \%$ - полевые шпаты, 0,4-4,1\% - углистые частицы, что свидетельствует о незначительном поступлении терригенного материала в солоноватоводный бассейн седиментации, где протекало формирование водорослевых образований.

В породах из верхнего интервала триасовых отложений (539,0-560,2 м) наблюдаются тесно соприкасающиеся и слабоуплотненные фрагменты известняков с различной структурой - от пелитоморфной и копролитовой до кристаллическизернистой с реликтами неопределимой фауны. Размеры фрагментов достигают 2-5 мм. Имеет место не только переработка остатков золотистых и сине-зелёных водорослей илоядными организмами, но и перемещение материала механическими микросдвигами и микросбросами за счёт разрушения слоев различной генетической природы и совмещения в одной части разреза различных по текстуре и структуре фрагментов. Материал частично доломитизирован и ангидритизирован. Скорее всего, это отложения обвальных фаций или результат влияния карста.

На глубине 539,2 м в составе брекчии, по всей вероятности, преобладают обломки среднетриасовых карбонатных образований ладинского яруса, в основном сероцветных, а также свойственный этому интервалу ржавый пигмент - это неоднократно переотложенные диспергированные гидроокислы железа. К тому же здесь найден фрагмент верхнетриасового кварцевого алевролита. Это позволяет с большой долей условности предполагать, что время преобразования данной части разреза, сложенной карбонатными осадками среднего триаса, вполне может быть связано с самыми верхами поздней юры. Позднеюрские брекчии большой мощности (до 500 м) с переотложенным материалом соляных куполов фиксируются на Царынской площади, в Сарпинском прогибе и в некоторых мульдах на юге Восточно-Европейской платформы [10].

В тяжелой фракции здесь отмечаются высокое количество ильменита $(42,5 \%)$, циркон $(5,7 \%)$, гранат (5,3\%). Эти компоненты, возможно, могли быть «вмыты» в осадки уже на стадии палеогипер- генных изменений брекчии во время длительного перерыва в осадконакоплении.

Между меловыми и триасовыми образованиями устанавливается угловое и стратиграфическое несогласие. Мощность пермо-триасовых пород надсолевого комплекса составляет всего 350 м, отражая низкий темп седиментации в триасовый период на рассматриваемой площади или наличие большого количества плохо определяемых перерывов в осадконакоплении.

Отсутствие в разрезе терригенных глинистых, алеврито- глинистых углесодержащих осадков заболачиваемых озер и песчаных осадков русел малых равнинных рек, свойственных верхнему триасу юго-востока Восточно-Европейской платформы [1], позволяет предполагать, что эти отложения могли формироваться, но вместе с юрскими были размыты в предпозднемеловое время. На сохранившихся от денудации карбонатных отложениях солоноватоводного бассейна, распространявшегося на этой территории в среднетриасовое время $[11,12]$, залегают типично морские отложения верхнего мела и палеогена.

Таким образом исследование особенностей надсолевых отложений Гремячинского месторождения калийных солей позволило установить присутствие в разрезе терригенных и хемогенно-терригенных отложений кунгурского яруса нижней перми, маломощные терригенные красноцветные отложения казанского яруса средней перми, отсутствие верхнепермских в современном понимании отложений, индского яруса нижнего триаса. Граница перми с нижним триасом выражена прослоем базального гравелита, сменяющегося алевритисто-глинистожелезистыми отложениями заиленных лагун с обильными следами деятельности и остатками типично морских илоедов. Верхняя часть оленекских отложений явно размыта. На границе с анизием залегает пачка рыхлого серого речного песка. Другая часть этого яруса представлена красноцветными алевролитами, песчаниками, остракодовыми известняками с органическими остатками переотложенными из нижнего триаса. Ладинские отложения представлены сероцветными водорослевыми известковыми породами и известняками. Породы верхней части ладинского яруса интенсивно брекчированы. Отложения верхнего триаса отсутствуют. Стратиграфический перерыв отвечает верхнему триасу, всей юре и нижнему мелу.

\section{Библиографический список}

1. Яночкина 3.А., Гучаки В.А., Иванов А.В. и др. Литолого-фациальные особенности отложений позднего фанерозоя юго-востока Восточно-Европейской платформы. Саратов, 2000. 114 с. (Тр. НИИ Геологии СГУ. Нов. cep. T. V).

2. Галкин С.В. Донная фауна гидротермали бассейна Манус // Океанология. 1990. Т. 30, вып. 5. С. 842-848. 
3. Яночкина 3.А., Букина Т.Ф. Об остатках шиповатых микроорганизмов и следах их жизнедеятельности в триасовых отложениях Мангышлака и Устюрта // Стратиграфия и палеонтология триасовых отложений Мангышлака и Устюрта. М., 1984.

4. Букина Т.Ф. О находках голотуриеподобных организмов и следах их жизнедеятельности в триасовых отложениях Западной Сибири // Триас Западной Сибири. Новосибирск, 2001. С. 172-175.

5. Букина Т.Ф., Яночкина 3.А. Биогенная минерализация организмов пригидротермальных сообществ триаса Мангышлака, Прикаспия, Западной Сибири // Минералогия и жизнь: происхождение биосферы и коэволюция минералбного и биологического миров, биоминералогия: Материалы IV междунар. семинара. Сыктывкар. 22-25 мая 2007 г. Сыктывкар, 2007. С. 86-87.

6. Московский Г.А., Свидзинский С.А. Соотношение ритмопачек и циклов седиментации в галогенных разрезах Северного Прикаспия // Советская геология. 1989. № 5. C. $49-54$.

УДК.551.763.3:563 (470.44)
7. Свидзинский С.А., Музалевский М.М., Ковальский Ф.И. Гремячинское месторождение сильвинитов // Новые данные по геологии соленосных бассейнов Советского Союза. M., 1986. C. 204-219.

8. Липатова В.В. О германском типе триаса в Прикаспийской впадине // Изв. АН СССР. Сер. Геол. 1967. № 1. C. 17-32.

9. Наумов А.Д. Пенеплены. Их геологическое значение как особой генетической категории материков. Саратов, 1981. C. 404.

10. Бабич Д.А., Самойлович В.Л. Хабарова Т.Н. О необычном характере пограничных слоев мела и юры в низовьях Волги // Докл. АН СССР. 1975. Т. 222, № 6. C. 1401-1403.

11. Липатова В.В. Триас юго-востока Восточно-Европейской платформы: Автореф. дис. ... д-ра геол.-минер. наук. Л., 1974.36 c.

12. Триас Прикаспийской впвдины и перспективы его нефтегазоносности / Под. ред. В.В. Липатовой. М., 1982. 152 с. (Тр. ВНИГНИ. Вып. 236).

\section{СТРАТИГРАФИЯ САНТОН-КАМПАНСКИХ ОТЛОЖЕНИЙ ЮГО-ВОСТОКА РУССКОЙ ПЛИТЫ НА ПРИМЕРЕ РАСЧЛЕНЕНИЯ РАЗРЕЗА У С. МЕЗИНО-ЛАПШИНОВКА И ПРОБЛЕМА ВНУТРИСАНТОНСКОЙ ГРАНИЦЫ В САРАТОВСКОМ ПОВОЛЖЬЕ}

\section{В.М. Харитонов, Е.М. Первушов ${ }^{1}$, В.А. Фомин ${ }^{1}$ \\ Саратовский государственный университет, отделение геологии НИИ ЕН \\ E-mail: niig@sgu.ssu.runnet.ru \\ ${ }^{1}$ кафедра исторической геологии и палеонтологии \\ E-mail: pervushovem@mail.ru}

Представлены результаты интерпретации биостратиграфического расчленения сантонских - кампанских отложений правобережья Саратовской области на примере проведенного ранее детального и комплексного изучения разреза в районе села Мезино-Лапшиновка. Изложены представления о достоверности вариантов детального, на уровне подъярусов, подразделения сантонского яруса применительно к территории правобережного Поволжья.

Ключевые слова: сантон-кампан, Саратовское Поволжье, разрез, стратиграфия, граница.

Stratigrafy of Santonian-Campanian Deposits of South-Easten Russian Platform on the Example of Section Separation Near the Village Mezino-Lapshinovka and the Problem of Intrasantonian Boundary in the Saratov Volga Region

\section{V.M. Kharitonov, E.M. Pervushov, V.A. Fomin}

The results of interpretation of biostratigraphic separation of santonian-campanian deposits of the Saratov right-bank Volga region, on the example of earlier conducted detailed and complex investigation of separation near the village Mezino-Lapshinovka have been pre-

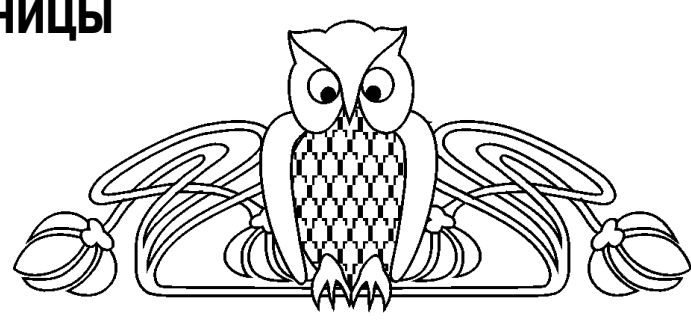

sented. The ideas of realiability of variants of the detailed (on the level of subtages) subdivision of santonian substage in reference to the territory of the Volga right-bank have been given.

Key words: santonian-campanian, Saratov Volga River Basin, crosssection, stratigraphy, boundary.

Территория европейской части России очень богата запасами углеводородного, рудного и нерудного минерального сырья. Нерудное минеральное сырье представлено писчими мелами, известняками, мергелями, песками, кремнистыми породами, фосфоритами и др., широко используемыми в различных отраслях народного хозяйства. Сейчас существует настоятельная потребность в поисках, разведке и доразведке месторождений нерудного минерального сырья с целью подсчета и увеличения их запасов. Все это связано с проведением геологосъемочных работ и расчленением опорных разрезов, в том числе и верхнемеловых отложений. В этом отношении очень интересным является разрез, расположенный в правобережной части Саратовской области у с. Мезино-Лапшиновка (рисунок). 